\title{
APLIKASI TEKNOLOGI PENGINDERAAN JAUH DAN SISTEM INFORMASI GEOGRAFIS DALAM PEMANTAUAN POTENSI SUMBERDAYA PESISIR DAN LAUT DI KABUPATEN PANGKEP
}

\author{
(Application of Remote Sensing Technology and Geographic Information System In \\ Monitoring Potentials of Coastal and Marine Resources In Pangkep Regency) \\ Abdul Rauf ${ }^{1)}$, Kamil Yusuf ${ }^{1)}$, Asmidar ${ }^{1)}$, Muh Kasnir ${ }^{2)}$, Mustamin Tajuddin ${ }^{3)}$ \\ 1) PS Ilmu Kelautan FPIK UMI \\ 2) PS Budidaya Perairan FPIK UMI \\ 3) PS Pemanfaatan Sumberdaya Perairan FPIK UMI \\ Korespondensi: arauf_umimksr@yahoo.com
}

Diterima: tanggal 2 September 2018; Disetujui 31 Oktober 2018

\begin{abstract}
Pangkep Regency has a large coastal area resource potential which is characterized by a long shoreline line of around $49.71 \mathrm{Km}$. Potential is spread along the coast which requires up-to-date information, namely position and area which is the basis for optimally and sustainably planning and managing coastal areas. The aim of this study is to map the potential of coastal ecosystem resources and coastal facilities along with their respective areas. This research uses a method with the Remote Sensing Technology and Geographic Information System (GIS) approach. The type of satellite data used is Spot-6 observation of 2018. The results obtained up-to-date data and information related to coastal area ecosystems and coastal facilities, namely mangrove ecosystems (327.22 ha), seagrass ecosystems (197.3 ha), coral reef ecosystems (0 Ha), artificial ecosystems in the form of ponds $(13,792,57 \mathrm{ha})$ and beach facilities in the form of seven fishing ports and piers. This data is expected to be a material consideration for policy makers of the Pangkep Regency government in developing and developing their coastal areas in the future
\end{abstract}

Keywords: Coastal ecosystems, remote sensing and GIS, satellite data

\begin{abstract}
ABSTRAK
Kabupaten Pangkep, memiliki potensi sumberdaya wilayah pesisir yang cukup besar yang ditandai dengan panjang garis pantainya sekitar $49,71 \mathrm{Km}$. Potensi tersebar disepanjang pantai yang membutuhkan informasi yang uptodate yakni posisi dan luasan dimana menjadi dasar didalam membuat perencanaan dan pengelolaan wilayah pesisir secara optimal dan berkelanjutan. Tujuan penelitian ini adalah untuk memetakan potensi sumberdaya ekosistem wilayah pesisir dan fasilitias pantai beserta luasannya masing-masing. Penelitian ini menggunakan metode dengan pendekatan Teknologi Penginderaan Jauh dan Sistem Informasi Geografis (SIG). Jenis data satelit yang digunakan adalah Citra Spot 6 observasi 2018. Hasil penelitian diperoleh data dan informasi yang uptodate terkait ekosistem wilayah pesisir dan fasilitas pantai, yaitu ekosistem mangrove (327,22 Ha), ekosistem padang lamun (197,3 Ha), ekosistem terumbu karang (0 Ha), ekosistem buatan berupa tambak (13.792,57 Ha) dan fasilitas pantai berupa pelabuhan dan dermaga perikanan sebanyak tujuh buah. Data ini diharapkan menjadi bahan pertimbangkan bagi pengambil kebijakan pemda Kabupaten Pangkep dalam membangun dan mengembangkan wilayah pesisirnya kedepan.
\end{abstract}

Kata Kunci : Ekosistem pesisir, penginderaan jauh dan SIG, data satelit 


\section{PENDAHULUAN}

Potensi sumberdaya wilayah pesisir dan laut adalah semua sumberdaya yang dapat memberikan manfaat bagi ummat manusia. Di wilayah pesisir dan laut terdapat tiga ekosistem utama yang merupakan penyedia sumberdaya alam yang ada diwilayah tersebut, yaitu ekosistem mangrove, padang lamun dan terumbu karang (Bengen, 2007; Dahuri, 2003). Ketiga ekosistem ini membutuhkan perhatian serius untuk mempertahankan keberadaannya, sehingga tidak mengalami kerusakan. Kaitan dengan ekosistem tersebut maka diperlukan data dan informasi tentang kondisinya yang setiap saat memerlukan updating, baik mengenai kondisi, luasan, lokasi maupun potensi yang dimiliki. Output dari kegiatan tersebut diharapkan dapat menghasilkan suatu informasi tentang potensi sumberdaya yang tersedia yang berguna bagi penggunanya.

Kegiatan inventarisasi potensi sumberdaya alam diwilayah pesisir dan laut membutuhkan waktu dan biaya yang cukup mahal, karena harus dilakukan survey lapangan agar mendapatkan data dan informasi yang akurat (Syah, 2010; Sudarsono, 2011). Atas dasar tersebut membutuhkan suatu cara atau metode untuk mendapatkan suatu output yang dapat menyajikan data dan informasi yang terkait dengan potensi sumberdaya tersebut dengan efisien dan murah. Salah satu teknologi yang dapat digunakan untuk hal tersebut adalah teknologi penginderaan jauh (remote sensing) dan system informasi geografis dengan memanfaatkan data citra satelit.

Penggunaan data citra satelit untuk monitoring sumberdaya wilayah pesisir dan laut memiliki beberapa keuntungan, yaitu mampu memonitor cakupan wilayah yang luas (Winarso, 2001; Kasim, 2012), mengurangi biaya jika dibandingkan dengan menggunakan pengukuran langsung, memerlukan waktu yang lebih pendek dalam menganalisa jika dibandingkan dengan pengukuran lapangan (Lillesand, 1999; Aryastana, et al. 2016)

Penelitian aplikasi teknologi penginderaan jauh dan system informasi geografis untuk memantau potensi sumberdaya pesisir dan laut ini bertujuan untuk memetakan potensi sumberdaya yang ada di wilayah pesisir Kabupaten Pangkajene Kepulauan (Pangkep) berikut luasannya. Hasil dari kajian ini diharapkan dapat menjadi bahan informasi, baik bagi pengambil kebijakan, stakeholder maupun terhadap mahasiswa. Data dan infomasi ini sangat berguna sebagai dasar dalam perencanaan dan pengelolaan wilayah pesisir khususnya di Kabupaten Pangkep.

\section{METODE PENELITIAN}

Metode pendekatan yang digunakan dalam penelitian ini adalah pendekatan survei dan aplikasi teknologi penginderaan jauh dan System Informasi Geografis (SIG). Penelitian ini dilaksanakan di sepanjang pantai wilayah pesisir Kabupaten 
Pangkep. Data citra satelit yang pemetaan potensi sumberdaya pesisir dan digunakan adalah SPOT-6 Observasi laut di Kabupaten Pangkep tersebut 2018, yang diolah dengan menggunakan digambarkan pada diagram alir yang SoftWare Ermapper V.7.1 dan ArGis disajikan pada Gambar 1.

V.13. Proses pelaksanaan kegiatan

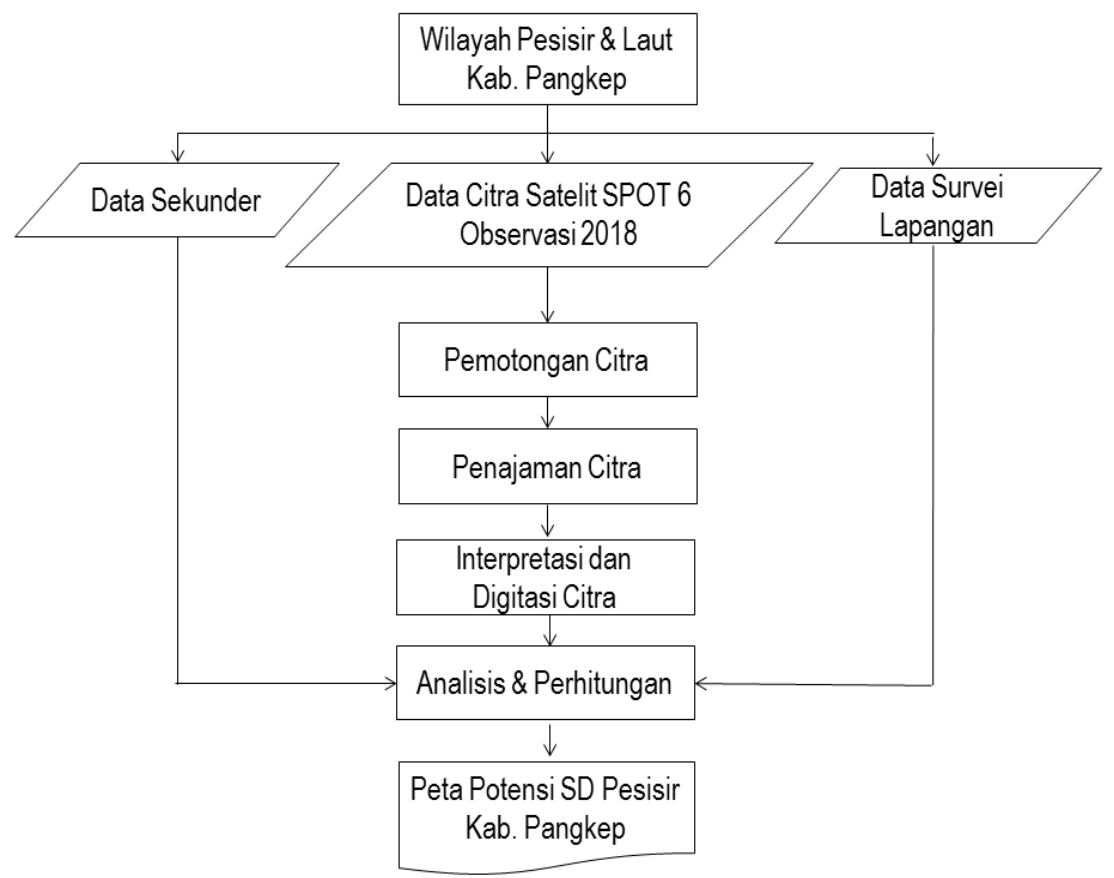

Gambar 1. Digram Alir Pembuatan Peta Potensi

HASIL DAN PEMBAHASAN

Berdasarkan hasil analisis interpretasi data citra satelit SPOT-6 tentang potensi sumberdaya pesisir dan laut Kabupaten Pangkep, diperoleh lima jenis potensi sumberdaya pesisir diwilayah tersebut, yaitu ekosistem buatan (tambak), ekosistem alami (mangrove, padang lamun), fasilitas pantai dan garis pantai. Adapun ukuran pada masing potensi tersebut dapat dilihat pada Tabel 1.

Tabel 1. Hasil Analisis Interpretasi Citra Satelit SPOT-6

\begin{tabular}{|c|c|c|c|c|}
\hline No. & $\begin{array}{c}\text { Jenis Potensi SD Pesisir dan } \\
\text { Laut }\end{array}$ & Ukuran & Satuan & Keterangan \\
\hline 1. & Tambak & $13.792,57$ & $\mathrm{Ha}$ & \\
\hline 2. & Mangrove & 327,22 & $\mathrm{Ha}$ & \\
\hline 3. & Padang Lamun & 128,14 & $\mathrm{Ha}$ & \\
\hline 4. & Terumbu Karang & 0 & $\mathrm{Ha}$ & Tidak ditemukan \\
\hline 5 & Fasilitas Pantai & 7 & buah & Pelabuhan/Dermaga \\
\hline 6. & Garis Pantai & 49,71 & $\mathrm{Km}$ & \\
\hline
\end{tabular}


Pengukuran dilakukan terhadap masing-masing potensi tersebut, kearah darat mulai dari garis pantai sampai dimana masih ditemukan tambak (udang/bandeng), sedangkan kearah laut mulai dari garis pantai sampai kurang lebih 1 mil laut. Dari tiga potensi ekosistem utama yang ada diwilayah pesisir dan laut, hanya ditemukan dua jenis di wilayah pesisir Kabupaten Pangkep, yaitu ekosistem mangrove dan padang lamun. Ekosistem terumbu karang tidak ditemukan disepanjang pantai karena disamping dibatasi hanya 1 mil laut, juga kondisi perairan diwilayah ini mempunyai sedimentasi yang cukup tinggi. Hal ini diduga disebabkan karena banyaknya muara sungai yang ada disepanjang pantai Kabupaten Pangkep. Peta sebaran pada masing-masing potensi tersebut disajikan pada Gambar 2.

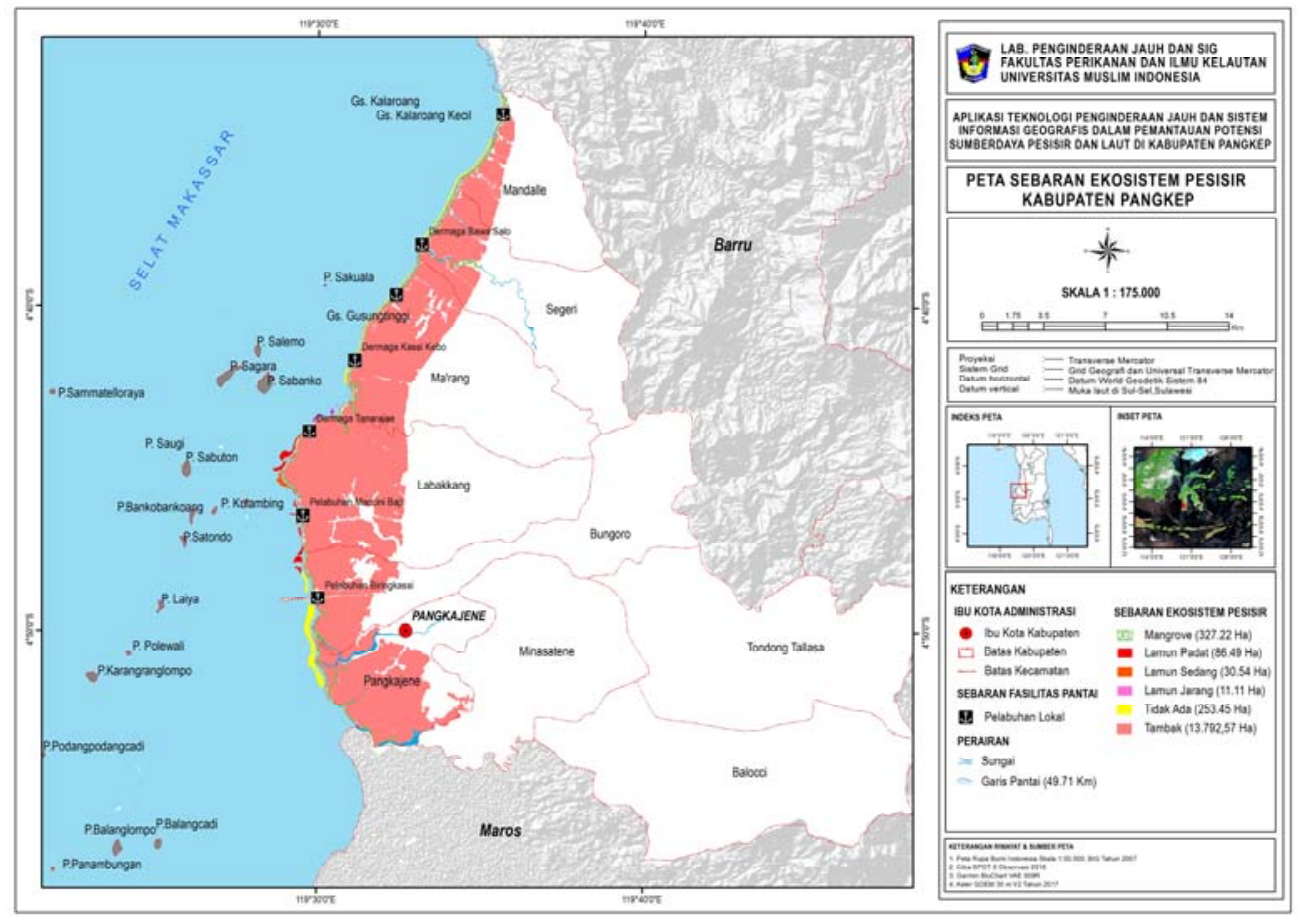

Gambar 3. Peta Sebaran Potensi Sumberdaya Pesisir dan Laut Kabupaten Pangkep

Data dan informasi yang diperoleh melalui pemetaan sebaran potensi ini yang disertai dengan luasan dan posisi masing-masing sangat berguna dalam mempersiapkan pengelolaan sumberdaya pesisir dan laut di Kabupaten Pangkep. Disamping itu diharapkan menjadi dasar dalam pengambilan kebijakan bagi pemerintah daerah khususnya di Kabupaten Pangkep dalam mempersiapkan perencanaan pengembangan potensi sumberdaya tersebut supaya dapat dimanfaatkan secara optimal dan berkelanjutan.

\section{KESIMPULAN}

Berdasarkan hasil analisis dan pembahasan diatas maka dapat disimpulkan sebagai berikut: 
1. Jenis potensi sumberdaya yang ditemukan di wilayah pesisir dan laut Kabupaten Pangkep yaitu ekosistem buatan (tambak), ekosistem alami (mangrove dan padang lamun), fasilitas pantai (pelabuhan/dermaga perikanan) dan panjang garis pantai.

2. Hasil pengukuran masing-masing jenis potensi tersebut adalah tambak 13.792,57 Ha, mangrove 327,22 Ha, padang lamun 128,14 Ha, panjang garis pantai $49,71 \mathrm{~km}$ dan 7 buah fasilitas pantai (pelabuhan/dermaga).

\section{SARAN}

Diharapkan kepada bagi pengambil kebijakan, stakeholder maupun terhadap mahasiswa, menjadikan rujukan hasil penelitian pada setiap kegiatan pemanfaatan dalam perencanaan dan pengelolaan wilayah pesisir khususnya di Kabupaten Pangkep.

\section{UCAPAN TERIMA KASIH}

Tulisan ini merupakan bagian dari penelitian dasar unggulan perguruan tinggi dan penulis mengucapkan terima kasih kepada Direktorat Riset dan Pengabdian Masyarakat, Direktorat Jenderal Penguatan Riset dan Pengembangan Kemnterian Riset, Teknologi dan Pendidikan Tinggi yang telah membiayai penelitian ini pada tahun anggaran 2018.

\section{DAFTAR PUSTAKA}

Aryastana, P., I.G.A.P. Eryani., dan K.W. Candrayana., 2016.
Perubahan garis pantai dengan citra satelit di Kabupaten Gianyar. Jurnal Ilmiah PADURAKSA, 5(2), 70-81

Bengen, D.G., 2001. Sinopsis Ekosistem Sumberdaya Alam Pesisir dan Laut. Pusat Kajian Pengelolaan Sumberdaya Pesisir dan Laut (PKSPL) IPB.

Dahuri, R., 2003. Keanekaragaman Hayati Laut, Aset Pembangunan Berkelajutan Indonesia. PT Gramedia Pustaka Utama. Jakarta

Kasim, F. (2012). Pendekatan Beberapa Metode dalam Monitoring Perubahan Garis Pantai Menggunakan Dataset Penginderaan Jauh Landsat dan SIG. Jurnal Ilmiah Agropolitan, 5(1), 620-623.

Lillesand, T. and Kiefer, R. 1999. "Remote Sensing and Image Interpretation". 4th Edition, John Wiley \& Sons Inc., ISBN 0-471-25515-7.

Sudarsono, B. (2011). Inventarisasi Perubahan Wilayah Pantai dengan Metode Penginderaan Jauh (Studi kasus Kota Semarang). Teknik, 32(2), 162169.

Syah, F.A., (2010). Penginderaan Jauh dan Aplikasinya di Wilayah Pesisir Dan Lautan. Jurnal Kelautan, Volume 3, No.1 April 2010.

Winarso, G., Budhiman, S., and Judijanto. (2001). The Potential 
Application of Remote Sensing Data for Coastal Study. Proceeding on 22nd Asian Conference on
Remote Sensing. Singapura: CRISP NUS and Asian Association on Remote Sensing. 